\title{
EFFECT OF K-SOURCES IN COMBINATION WITH GIBBERELLIC ACID ON MAIZE PRODUCTION UNDER WATER STRESS IN SANDY SOIL
}

\author{
Y. M. EL-Edfawy, S. Mohamed and E.M. Aly \\ Soil, Water and Environment Research Institute, Agric., Res. Center, Giza, Egypt. \\ Received: Jan. 4, 2021
}

Accepted: Feb. 23, 2021

\begin{abstract}
A field experiment was conducted along the two successive summer seasons of 2019 and 2020 under sandy soil conditions at Ismailia Agricultural Research Station. This study aim to evaluate the effect of $K$ sources i.e. K-silicate and K- humate, combined with gibberellic acid application under different irrigation levels on yield characters and NPK uptake by maize plant (Zea maize L.). The experimental treatments were arranged in a split -split plot design as follows: (1) three irrigation levels were assigned as main plots i.e. $100 \%\left(I_{1}\right) 80 \%\left(I_{2}\right)$ and $60 \%\left(I_{3}\right)$ of maize evapotranspiration $\left(E T_{c}\right),(2)$ three treatments of $\mathrm{K}$-source as foliar application were arranged as sub plot i.e. 0 , K-humate at rate of $4 \mathrm{~g} \mathrm{~L}^{-1}$ and K-silicate at rate of $150 \mathrm{mg} \mathrm{L}^{-1} \mathrm{Si}(3)$ three application rates of gibberellic acid $0\left(G_{0}\right), 100\left(G_{1}\right)$ and $150\left(G_{2}\right) \mathrm{mg} \mathrm{L}^{-1}$ were arranged as sub-sub plots. The obtained results indicated that the heist values of grain yield, straw yield and NPK- uptake by plant were recorded at treatment of $\mathrm{I}_{2}{ }^{*} \mathrm{~K}_{\text {humate }}{ }^{*} \mathrm{GA}_{1}$. Soil content of available $\mathrm{N}$ was significantly increased with the foliar spraying of the K-silicate, $\mathrm{K}$ humate and the different levels of gibberellic acid, but not significantly affected by irrigation levels. Soil available $P$ was not significantly affected by different treatments while, soil available $K$ was significantly affected by irrigation level, K-silicate and Khumate but not significantly affected by the different levels of Gibberellic acid.
\end{abstract}

Key words: Maize; Irrigation level; K-humate; K-silicate; and Gibrillic acid

\section{INTRODUCTION}

Foliar spraying for maize with potassium silicate and potassium humate are one of the major popular replacements in chemical and nature compound for plant development. It' can improve plant tolerance against many stress factors, assists plants to stay alive in water shortage conditions, and decrease transpiration. In sandy soil water deficit is one of the major factors that affects critical growth stages and crop production. In tropical countries where yield decline or stagnation is a problem, the silicon management increase yield, sustain crop productivity which is necessary in high temperatures. It can also develop integrated nutrients and help overcome low leaching process and soil erosion (Meena et al., 2014). In sandy soils where Irrigation water applied at 5955, 4762 and $3572 \mathrm{~m}^{3} \mathrm{ha}^{-1}$, IWUE, maize yield, yield components significantly increased with increasing irrigation rates and decreasing population densities (El-Hendawy et al., 2008).Atta (2014)reported that the highest of plant height, ear diameter, ear height, ear length, ear weight, number of ears/plant, 100-kernel weight and grain yield for maize cultivars were achieved at irrigation treatment of $5676.0 \mathrm{~m}^{3} \mathrm{ha}^{-1}$ irrigation as compared with 8143.0 and $3810.0 \mathrm{~m}^{3} \mathrm{ha}^{-1}$. (Ewis et al., 2016) noted that full irrigated maize plants with 3525 and $3590 \mathrm{~m}^{3}$ fed $^{-1}$ with $150 \mathrm{~kg} \mathrm{~N} \mathrm{fed}^{-1}$ inducing the highest effect on plant height, 100- grain weight, weight of

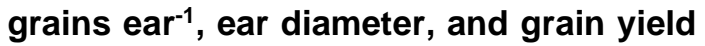
while, treatment as 2723 and $2773 \mathrm{~m}^{3}$ fed $^{-1}$ were the lowest recorded .In Egypt, water requirements recommended for 
maize under current climate range between 772 to $1090 \mathrm{~mm}$ and water requirements under climate change range between 859 to $1290 \mathrm{~mm}$ (Ouda et al., 2018). Irrigation water required yearly ranged between 390 to $575 \mathrm{~mm}$ water for maize growth stages as non-stressed production, and caused positive effect on maize grain yield (Recep, 2004). Stage of the falling rate began after 5 days of evaporation and during the falling rate stage; moisture content of the sandy soil increased exponentially, in the tropics. The best control of soil water loss would be the constant rate stage(Mensah,1997).

Foliar spraying with potassium silicate and potassium humate at 1,2 , and $4 \mathrm{~cm} \mathrm{~L}^{-1}$ reduce the negative effects of soil salinity stress and showed significant increase on growth, yield, and yield Attributes, chemical contents in the leaves and seeds and quality of pea while potassium humate at different rates significantly increased all parameters (Ismail et al., 2017).Also, water irrigation could be necessary to sandy soil and new management such as K-humate and Ksilicate can increase maize yield in these conditions. Sandy soil has low Si soluble concentrations which are prone to water deficit. Si content $\left(0.9 \mathrm{mg} \mathrm{kg}^{-1}\right.$ sandy soil) can lead to positive effect of Si application at $600 \mathrm{~kg} \mathrm{ha}^{-1}$ (Camargo et al., 2014). In maize, addition of silicon can affect some physiological activities, increase amounts of nutrients, increase osmo-regulators and improve tolerance against water stress and plant growth under deficit water. Silicon has an important role in the mineral balance and it can increase the Kcontent (Asgharipour and Mosapour, 2016). Silicon with foliar application can be used with stressful conditions for cereals crops such as salinity, excess or deficiency of water. It also showed to increase the yield of crops in the last $\mathbf{1 5}$ years (Arkadiusz, 2018). Silicon fertilization significantly showed superior effect on carbohydrate, stalk yield, dry biomass and water deficit compared to its absence. Si at planting reduced the damage caused by water deficit (Camargo et al., 2017). Foliar application of silica-nano increase in plant growth, yield, quality and biotic stress (HenkMaarten 2018). Potassium silicate at 200 $\mathrm{ml} \mathrm{L}^{-1}$ with $40 \mathrm{~mm}$ water increased leaf water potential, growth, total dry biomass, net photosynthetic rate and decreased shoot to root ratio, decreased leaf water potential and transpiration in sorghum cultivars (Mukhtar et al., 2011).

Application of Salicylic acid sprays to maize plants at concentrations of 1 to 3 $\mathrm{mL} \mathrm{L}^{-1}$ (7 to $22 \mathrm{ppm} \mathrm{Si}$ ) in sandy loam soil increase the growth, yield and yield component (Jawahar et al., 2017). Foliar sprays with $2 \mathrm{~mL} \mathrm{~L}^{-1}$ (15 ppm Si) Salicylic acid increased $N, P, K$ and Si content in the leaves of white, shoot dry matter, NO. of panicles, NO. of grains per panicle and increased significantly grain yield (Soratto et al., 2012). Liquid potassium

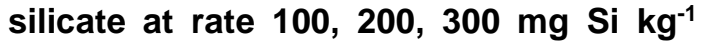
added to plant showed positive effect

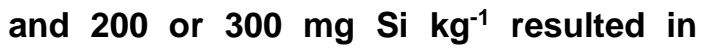
highly significant growth parameters and yield (Ratnayake et al., 2016). In the USA, with applying silicon at 59, 118 and 236 mg $\mathbf{~ k g}^{-1}$, beneficial rates effect was observed in the winter wheat irrigated (Walsh et al., 2017). Foliar application of both potassium silicate at rate $8.5 \mathrm{mM}$ and salicylic acid at $2 \mathrm{mM}$ can be considered as an optimal treatment to vegetative growth, good quality and can also produce high yield (Abd-Elaziz et al., 2019). Potassium silicate $\left(6.0 \mathrm{~cm}^{3} \mathrm{~L}^{-1}\right)$ as foliar application gave the highest increases of NPK in leaves, growth, plant dry weight, quality of garlic, yield and yield component (Zyada and Bardisi, 2018).

In sandy soil, K-humate has improved soil physical, chemical, biological properties, crop yield and nutrients 
(Hussein and Hassan, 2011). A small concentration of humic substances has shown positive effect on shoot length, plant growth parameters, root length, moisture and nutrient contents (YImaz, 2007). K-humate improves soil physical, chemical properties and nutrient movements (Abd-All et al., 2017).

Humic substances have increased nutrients efficiency, plant biomass and plant growth. Humic substances can improve the root growth and contents of $\mathrm{N}, \mathrm{P}$ and $\mathrm{K}$, under stress such as salinity (Rose et al., 2014). Humic substances showed improvement of the soils physical properties and moisture contents, CEC, yield quality and soil productivity (Zhang and He, 2004). HA or K-humate fractions increased availability $P$, hydrolysable $P$ and crop uptake (Zhongqi et al., 2011). Humic acid increased yield components, soil pH, organic carbon, NPK contents, available NPK (Dongfeng et al., 2016). Humic acid can increase plant growth, nitrogen uptake, and transport of potassium, phosphorus and calcium for plants. Humic acid, improved exchangeable calcium, total phosphorus, cation exchange capacity and total nitrogen (Jamala and Oke, 2013). The spray solution of K-humate added at rate 0.5 to $10 \%(\mathrm{w} / \mathrm{v})$ showed positive effect on seed germination and root, gave highest yield and NPK under the soil salinity stress(Abdel-Rahman, 2017). The foliar application of liquid humic acids at $0,0.1$ and $0.2 \%$ under salt stress increased the maize uptake of $\mathrm{N}, \mathrm{P}$ and $\mathrm{K}$ (Hussein and Hassan, 2011). K-humate at $0.5 \%$ and $1.0 \%$ solution increased yield, yield components and plant growth parameters (Harshad et al.,2018).

Application of gibberellic acid (GA) is the main controlling, readily available, sustainable, low costs, measures that is less expensive with minimal environmental hazards (Cumagun and Moosavi, 2015). Application spray of GA in sandy soil under salt stress through 60 days after sowing improved all the growth parameters, physio-biochemical characters, electrolyte leakage, proline, thiobarbituric acid reactive, activities of superoxide, glycine betaine, content activities of superoxide dismutase, catalase and leaf nutrients content (Nasir Khan et al., 2012). Application of GA to the cereal roots improve growth root, tall, exogenous, leaf elongation and reduced number of tillers (Mauricio et al., 2013). Moreover, involvement in the roots growth is highly sensitive to added GA and rapidly increase root growth rates than for shoots (Tanimoto, 2012). Foliar spray at 25 and 35 days after sowing GA at 50 and $100 \mathrm{ppm}$ caused significant increase in 1000 seeds of pea, length of pod, NO of pods I plant, NO of seeds I pod, pods fresh, dry weights, increase in total soluble carbohydrates, total chlorophylls, total proteins, phenol, sugars in seeds, endogenous phytohormones in seeds and GA concentration in plants (El-Shraiy and Hegazi, 2009). Foliar application of GA at $20 \mathrm{ppm}$ was the promising treatment under sandy soil condition for increasing productivity, yield, fruit retention, increased fruit set, decreased fruit drop and improved the physical and chemical fruit characteristics (Abd El-Moneim et al., 2007).GA at rate $0.25,0.82,2.03,5.38$ and $5.76 \mathrm{ppm}$ showed positive effect on plant growth-promoting ability and fungi (Sumera et al., 2009).

This study aim to evaluate the effect of $\mathrm{K}$ source i.e. $\mathrm{K}$-silicate and $\mathrm{K}$ - humate, combined with gibberellic acid application under different irrigation levels on yield characters and NPK uptake of maize plant (Zea maize L.) and water use efficiency. 


\section{MATERIALS AND METHODS}

\section{Site description}

These field experiments were conducted two successive during summer grown seasons of 2019 and 2020 under sandy soil conditions; Entisol [Arenosol AR] of the Farm Ismailia Agricultural Research Station, Agricultural Research Center (ARC) Egypt (30³5' 42.9"N 32¹6'51"Eelevation $14 \mathrm{~m})$. Main properties of physical and chemical soil were carried out according to Page et al. (1982) and obtained data are shown in Table 1.

\section{Climatic condition:}

The meteorological data at Ismailia Station, Egypt were obtained from the agro meteorological unit at SWERI, ARC had been daily recorded and their monthly mean values were calculated during the last ten years period and presented in Table 2.

\section{Experimental design and treatments}

The experimental treatments were arranged in a split -split plot design including 27 treatments with three replicates. The experiment included 3 factors as follows: (1) three irrigation levels were assigned to main plots i.e. $100 \%\left(I_{1}\right) 80 \%\left(I_{2}\right)$ and $60 \%\left(I_{3}\right)$ of maize evapotranspiration $\left(E_{\mathrm{c}}\right)(2)$ three treatments of K-source as sub plot $K_{0}$ without application, K-humate at rate of 4 $\mathrm{g} \mathrm{I}^{-1}$ and K-silicate at rate of $150 \mathrm{mg} \mathrm{l}^{-1} \mathrm{Si}$ (3) three application rates of gibberellic acid $0\left(G_{0}\right), 100\left(G_{1}\right)$ and $150\left(G_{2}\right) \mathrm{mg} \mathrm{l}^{-1}$ as sub-sub plots. Each source of $K$ and gibberellic acid was applied at $3000 \mathrm{I} \mathrm{ha}^{-1}$

Table 1. Main characteristic of the studied soil.

\begin{tabular}{|c|c|c|c|c|c|c|c|c|c|c|c|c|c|}
\hline \multicolumn{4}{|c|}{$\begin{array}{l}\text { Particle size distribution } \\
(\%)\end{array}$} & \multirow{2}{*}{$\begin{array}{l}\text { Texture } \\
\text { class }\end{array}$} & \multirow{2}{*}{$\begin{array}{c}\text { Bulk } \\
\text { density } \\
\left(\text { Mgm }^{-3}\right)\end{array}$} & \multirow{2}{*}{$\begin{array}{c}\text { Organic } \\
\text { matter } \\
\text { g kg-1 }\end{array}$} & \multicolumn{3}{|c|}{$\begin{array}{l}\text { Available } \\
\text { nutrients } \\
\left(\mathrm{mg} \mathrm{kg}^{-1}\right)\end{array}$} & \multirow{2}{*}{${ }^{*} \mathrm{pH}$} & \multirow{2}{*}{$\left(\mathrm{dSm}^{*-1}\right)$} & \multirow{2}{*}{$\begin{array}{l}\text { CEC } \\
\text { (cmolc/kg } \\
\text { soil) }\end{array}$} & \multirow{2}{*}{$\begin{array}{l}\mathrm{CaCO}_{3} \\
\mathrm{~g} \mathrm{~kg}^{-1}\end{array}$} \\
\hline $\begin{array}{c}\text { Coarse } \\
\text { sand }\end{array}$ & $\begin{array}{l}\text { Fine } \\
\text { sand }\end{array}$ & Silt & Clay & & & & $\mathbf{N}$ & $\mathbf{P}$ & K & & & & \\
\hline 71.14 & 23.86 & 3.36 & 1.64 & Sandy & 1.84 & 1.28 & 11.22 & 3.25 & 60 & 8.01 & 1.10 & 1.10 & 7.15 \\
\hline
\end{tabular}

*pHsoil: water suspension at 1: 2.5,EC in soil saturation extract

Table 2. The meteorological data of Ismailia Station during the last ten years (2010 -2020) period.

\begin{tabular}{|c|c|c|c|c|c|c|c|c|c|c|c|}
\hline Month & $T_{\text {max. }}{ }^{\circ} \mathrm{C}$ & $\mathrm{T}_{\min .}{ }^{\circ} \mathrm{C}$ & $\mathrm{T}_{\text {mean }}{ }^{\circ} \mathrm{C}$ & $\underset{\%}{\mathrm{RH}_{\max } .}$ & $\underset{\%}{\mathrm{RH}_{\min }}$ & $\mathrm{RH}_{\text {mean }} \%$ & $\begin{array}{l}\text { W.S m } \\
\text { sec }^{-1}\end{array}$ & $\stackrel{\mathrm{N}}{\text { hour }_{\text {min }}}$ & $\stackrel{\mathrm{N}}{\text { hour }_{\max }}$ & $\underset{{ }^{2} \text { day }^{-1}}{\text { RsMJm- }^{-}}$ & $\begin{array}{c}\mathbf{R a} \\
\mathrm{MJm}^{-} \\
{ }^{2} \text { day }^{-1}\end{array}$ \\
\hline May & 31.9 & 17.7 & 24.5 & 61.2 & 20.8 & 41 & 3.15 & 10.3 & 13.6 & 26.99 & 40 \\
\hline June & 35 & 21.2 & 27.5 & 67.6 & 22.8 & 45.2 & 3 & 13.1 & 13.97 & 29.7 & 41.27 \\
\hline July & 35.9 & 23.2 & 29 & 72.8 & 28 & 50.4 & 3 & 12.6 & 13.83 & 28.67 & 40.63 \\
\hline August & 36.25 & 23 & 29.1 & 75.4 & 28.4 & 51.9 & 2.8 & 12.2 & 13.13 & 27.13 & 37.97 \\
\hline
\end{tabular}

Tmax: maximum air temperature, $T_{\min }$ : minimum air temperature, $T_{\text {mean: }}$ mean air temperature, $\mathrm{RH}_{\text {max }}$ : maximum relative humidity, $\mathrm{RH}_{\min }$ : minimum relative humidity, $\mathrm{RH}_{\text {mean }}$ : mean relative humidity, W.S:wind speed, $\mathbf{N}$ hour ${ }_{\min }$ : minimum daylight hours, $\mathbf{N}$ hourmax: maximum daylight hours, Rs: solar radiation and Ra: extraterrestrial radiation. 
Potassium silicate fertilizer $\left(\mathrm{K}_{2} \mathrm{SiO}_{3}\right)$ contained $114 \mathrm{~g} \mathrm{Si} \mathrm{kg-1}$ and $500 \mathrm{~g} \mathrm{~K} \mathrm{~kg}^{-1}$ imported by Technogene Company, China and prepared through mixed $1.32 \mathrm{~L}$ $\left(150 \mathrm{~g} \mathrm{Si} \mathrm{l}^{-1}\right) \mathrm{K}$ - silicate with $998.68 \mathrm{I} \mathrm{ha}^{-1}$ irrigation water. Liquid fertilizer of $\mathrm{K}$ humate (5\% humic acid) prepared by mixed $4 \mathrm{~kg}$ K-humatewith1000.0 I hairrigation water. Main properties of $\mathrm{K}$ humate are shown in Table 3. Gibberellic acid solution prepared through mixed $\mathbf{5 0}$ and $100 \mathrm{~cm}^{-3}$ from gibberellic acid with irrigation water and kept it solution spray at 1000 liter total.

\section{Irrigation system}

Three irrigation levels i.e. $100 \%, 80 \%$ and $60 \%$ of maize evapotranspiration $\left(E T_{C}\right)$ were assigned. Levels of ETc at the maize growth season are presented in Table 4.

Crop evapotranspiration (ETc) under varying irrigation levels was calculated as follows:

$$
\mathrm{ET}_{\mathrm{c}}=\mathrm{K}_{\mathrm{c}} \times \mathrm{ET}_{\mathrm{o}}
$$

Where: $\mathrm{Kc}$ is the crop coefficient Kc was calculated by Doorenbos and Kassam (1979) are 0.4, 0.775 for the initial, development, respectively. While, the adjust maize crop coefficient $K_{c}$ calculated by the next equation are 1.22 and $\mathbf{0 . 4 7 9}$ for mid-season and late-season corroding Allen et al. (1998), respectively.

$\mathrm{K}_{\mathrm{c} \text { mid }}=\mathrm{K}_{\mathrm{c} \operatorname{mid}(\mathrm{Tab})}+\left[0.04\left(\mathrm{u}_{2}-2\right)-0.004\left(\mathrm{RH}_{\min }-\right.\right.$ 45)] $(\mathrm{h} / 3)^{0.3}$

$\mathrm{K}_{\mathrm{c} \text { end }}=\mathrm{K}_{\mathrm{c} \text { end }(\mathrm{Tab})}+\left[0.04\left(\mathrm{U}_{2}-2\right)-0.004\left(\mathrm{RH}_{\min }-\right.\right.$ 45) $](h / 3)^{0.3}$

$\mathrm{ET}_{\mathrm{o}}$ was calculated by Penman-Monteith formula (Allen et al. 1998):

$$
E T_{0}=\frac{0.408 \Delta\left(R_{n}-G\right)+Y \frac{900 U_{2}\left(e_{s}-e_{a}\right)}{T+273}}{\Delta+Y\left(1+0.34 u_{2}\right)}
$$

Where: ETO is the referenced crop evapotranspiration ( $\mathrm{mm}$ day $\left.^{-1}\right), \mathrm{Rn}$ is the surface net radiation $\left[\mathrm{MJm}^{-2}\right.$ day $\left.^{-1}\right]$, $\mathrm{G}$ soil heat flux density $\left[\mathrm{M} \mathrm{J} \mathrm{m}^{-2}\right.$ day $\left.^{-1}\right], \mathrm{T}$ mean daily air temperature at $2 \mathrm{~m}$ height $\left[{ }^{\circ} \mathrm{C}\right]$, $\mathrm{U}_{2}$ wind speed at $2 \mathrm{~m}$ height $\left[\mathrm{ms}^{-1}\right], \mathrm{e}_{\mathrm{s}}$ saturation vapor pressure $\left[K P_{a}\right], e_{a}$ actual vapor pressure $\left[K_{\mathrm{a}}\right], \mathrm{e}_{\mathrm{s}}-\mathrm{e}_{\mathrm{a}}$ saturation vapor pressure deficit $\left[K P_{a}\right], \Delta$ slope vapor pressure curve $\left[\mathrm{K} P_{\mathrm{a}}{ }^{\circ} \mathrm{C}^{-1}\right], \mathrm{Y}$ psychometric constant $\left[\mathrm{K}_{\mathrm{a}}{ }^{\circ} \mathrm{C}^{-1}\right]$.

Table 3. Main characteristics of the applied K-humate.

\begin{tabular}{|c|c|c|c|c|c|c|c|}
\hline $\begin{array}{c}* \mathrm{EC} \\
\left(\mathrm{dSm}^{-1}\right)\end{array}$ & $* \mathrm{pH}$ & $\begin{array}{c}\text { Total } \\
\mathbf{C} \\
\left(\mathbf{g ~ k g} \mathbf{~}^{-1}\right)\end{array}$ & $\begin{array}{c}\text { Total } \\
\mathbf{N} \\
\left(\mathbf{g ~ k g}^{-1}\right)\end{array}$ & $\begin{array}{c}\text { Total } \\
\mathbf{P} \\
\left(\mathbf{g ~ k g}^{-1}\right)\end{array}$ & $\begin{array}{c}\text { Total } \\
\mathbf{K} \\
\left(\mathbf{g ~ k g}^{-1}\right)\end{array}$ & $\begin{array}{c}\text { Total } \\
\mathbf{M g} \\
\left(\mathbf{g ~ k g}^{-1}\right)\end{array}$ & $\begin{array}{c}\text { Total } \\
\mathbf{C a} \\
\left(\mathbf{g ~ k g}^{-1}\right)\end{array}$ \\
\hline 8.34 & 7.29 & 486.0 & 38.9 & 3.42 & 96.1 & 10.50 & 5.70 \\
\hline
\end{tabular}

\begin{tabular}{|c|c|c|c|c|c|c|c|c|c|c|}
\hline \multirow[b]{2}{*}{ Treatments } & \multicolumn{2}{|c|}{ May* } & \multicolumn{2}{|c|}{ June } & \multicolumn{2}{|c|}{ July } & \multicolumn{2}{|c|}{ August** } & \multirow[b]{2}{*}{$\begin{array}{c}\text { Total } \\
\text { mm }\end{array}$} & \multirow{2}{*}{$\begin{array}{l}\text { Total } \\
\mathrm{m} 3 \text { /ha }\end{array}$} \\
\hline & $\begin{array}{c}\text { Daily } \\
\text { mm }\end{array}$ & $\begin{array}{c}\text { Monthly } \\
\mathrm{mm}\end{array}$ & $\begin{array}{c}\text { Daily } \\
\text { mm }\end{array}$ & $\begin{array}{c}\text { Monthly } \\
\text { mm }\end{array}$ & $\begin{array}{c}\text { Daily } \\
\text { mm }\end{array}$ & $\begin{array}{c}\text { Monthly } \\
\text { mm }\end{array}$ & $\begin{array}{r}\text { Daily } \\
\text { mm }\end{array}$ & $\begin{array}{c}\text { Monthly } \\
\text { mm }\end{array}$ & & \\
\hline $100 \% \mathrm{ET}_{\mathrm{c}}$ & 4.03 & 125 & 6.67 & 200.2 & 10.06 & 312 & 4.84 & 150.1 & 787 & 7870 \\
\hline $80 \% \mathrm{ET}_{\mathrm{C}}$ & 3.22 & 99.82 & 5.34 & 160.2 & 8.05 & 249.5 & 3.87 & 120.03 & 629.6 & 6296 \\
\hline $60 \% \mathrm{ET}_{\mathrm{c}}$ & 2.42 & 75.02 & 4 & 120 & 6.04 & 187.12 & 2.9 & 90 & 472.2 & 4722 \\
\hline
\end{tabular}

EC at (solution 1: 5), pH at (solution 1: 5)

Table 4. Maize evapotranspiration $\left(\mathrm{ET}_{\mathrm{c}}\right)$

* Sowing date at first of May ** Harvest date at 31 of August 
Irrigation formed $15 \mathrm{~mm}$ at initial stage as recommended maize soil water depletion. Then, irrigation formed $22 \mathrm{~mm}$ at next stages. This range of soil water depletion represents between $50 \%$ of total available soil water in the root depth.

\section{Crop managements}

Zea maize (Zea mays $L$. hybrids single cross 310) grain were sown in the first day of May 2019 and 2020 under sprinkler irrigation system. One grain/hill were manual sowing with $25 \mathrm{~cm}$ apart between hills. Four foliar spraying times of Khumate, K-silicate and gibberellic acid were applied at $30,45,60$ and 75 days from sowing. Nitrogen fertilizer was added as ammonium sulfate $(200 \mathrm{~g} \mathrm{~N}$ $\mathrm{kg}^{-1}$ ) at rate of $285.6 \mathrm{Kg} \mathrm{N} \mathrm{ha}^{-}$ ${ }^{1}$.Phosphorus was applied in the form of super phosphate $\left(0.068 \mathrm{~kg} \mathrm{P} \mathrm{kg}^{-1}\right)$ at rate of $16.09 \mathrm{P} \mathrm{ha}^{-1}$ during the final stage of land preparation for planting and potassium was added in the form of potassium sulphate $\left(0.398 \mathrm{~kg} \mathrm{~K} \mathrm{~kg}^{-1}\right)$ at rate of $95 \mathrm{~kg} \mathrm{~K} \mathrm{ha}^{-1}$ in two equal doses after sowing and flowering.

The experimental unit area was $\mathbf{1 0 . 5}$ $\mathrm{m}^{2}$ with dimensions $3 \times 3.5 \mathrm{~m}$, each plot included 4 ridges ( $3.5 \mathrm{~m}$ in length and 30 cm in width).

\section{Soil and plant analyses}

After harvesting disturbed and undisturbed soil samples were collected from surface layer $(0-30 \mathrm{~cm})$ to determine physical and chemical soil properties according to Klute (1986). Total carbonate content (\%) was determined volumetrically using Collin's calcimeter (Page et al., 1982). Organic matter was determined by the chromic acid method of Walkely and Black (Jackson 1973). Available $\mathrm{N}$, total $\mathrm{N}$ were estimated by distillation using Kjeldahl apparatus and $K$ indicator by the flame photometer apparatus. Available phosphorus extracted by $(0.5 \mathrm{~N}) \mathrm{NaHCO}_{3}$ solution as described by Olsen et al. (1954) by using of molybdate and stannous chloride according Page et al. (1982).

Harvesting was carried out after about 140 days after planting. The plants were air dried. Samples of plants at harvesting as well as grain and straw were oven dried at $72^{\circ} \mathrm{C}$ for $48 \mathrm{~h}$ and digested by using sulfuric $\left(\mathrm{H}_{2} \mathrm{SO}_{4}\right)$ and per chloric acid ( $\left.\mathrm{HClO}_{4}\right)$ - mixed (1:1) Page et al., 1982.

\section{RESULTS AND DISCUSSIONS}

\section{Yield of maize plant}

Data presented in Tables 5 and 6 showed that the main effect of water deficit, K-sources and gibberellic acid application and their interactions on yield characters of maize plant. Results clear that all yield characters of maize plant were affected significantly by the different levels of irrigation. The results indicated the superiority of the yield characters at $100 \%$ from ETc of maize plant, this treatment gave higher average of grain and straw yields as compared with treatments of $80 \%$ and $60 \%$ of ETc these results are in agreement with those obtained by AI-Shaheen and Ismael, (2016) and Al-Shaheen and Awany, (2018).

Regarding to the individual effect of Ksource as a foliar application, data in the same Tables ( 5 and 6 ) indicated that the treatments of $K_{\text {silicate }}$ and $K_{\text {humate }}$ had a significant effect on grain and straw yields, harvest index, crop index and shelling yield of maize plant compare with the unfertilized treatment $\left(K_{0}\right)$. The highest mean value of all yield character were obtained when the plants were sprayed with K-humate at a rate of $\mathbf{4 0 0 0}$ $\mathrm{mg} \mathrm{L}^{-1}$ compared with k-silicate at a rate of $150 \mathrm{mg} \mathrm{L}^{-1}$ and also there was a significant effect between them. This 
trend attributed to that the K-humate contains many elements which improve the plant growth and yield. These results are in accordance with this obtained by (El-Bassiony et al., 2010; Ahmed et al., 2017; and El-Edfawy 2017).

With respect to the effect of gibberellic acid on yield character of maize plant, the results of statistical analysis showed superiority of the treatmentGA $A_{1}$ with a significant difference from the other levels of gibberellic acid spraying. The lowest values in all yield characters were recorded when did not spray by gibberellic acid (control treatment). Also there were a significant difference between the two levels of gibberellic acid $\left(G A_{1}\right.$ and $\left.G_{2}\right)$. These results are consistent with Al-Shaheen and Awany (2018) and Qasim et al. (2018).

Table 5. Effect of water deficit, $\mathrm{K}$ source and foliar application of gibberellic acid on grain and straw yield of maize plant (average of two seasons).

\begin{tabular}{|c|c|c|c|c|c|c|c|c|c|}
\hline \multirow{3}{*}{ Irrigation } & \multirow{3}{*}{$\begin{array}{c}\mathrm{K} \\
\text { source }\end{array}$} & \multicolumn{8}{|c|}{ Gibberelic acid } \\
\hline & & $\mathrm{GA}_{0}$ & $\mathrm{GA}_{1}$ & $\mathrm{GA}_{2}$ & Means & $\mathrm{GA}_{0}$ & $\mathrm{GA}_{1}$ & $\mathrm{GA}_{2}$ & Means \\
\hline & & \multicolumn{4}{|c|}{ Grain yield (kg ha-1) } & \multicolumn{4}{|c|}{ Straw yield $\left(\mathrm{kg} \mathrm{ha}^{-1}\right)$} \\
\hline \multirow{3}{*}{$\mathbf{I}_{\mathbf{1}}$} & $\mathrm{K}_{\mathbf{0}}$ & 2061.00 & 3120.00 & 3019.42 & 2733.47 & 2147.67 & 2437.67 & 2732.67 & 2439.34 \\
\hline & $\mathrm{K}_{\text {silicate }}$ & 2277.33 & 6543.33 & 5558.00 & 4792.89 & 2652.50 & 7994.67 & 5836.67 & 5494.61 \\
\hline & Khumate & 2374.00 & 7341.67 & 7396.33 & 5704.00 & 2673.33 & 8991.90 & 7390.00 & 6351.74 \\
\hline \multicolumn{2}{|c|}{ Means } & 2237.44 & 5668.33 & 5324.58 & 4410.12 & 2491.17 & 6474.74 & 5319.78 & 4761.90 \\
\hline \multirow{3}{*}{$\mathbf{I}_{2}$} & $\mathrm{~K}_{0}$ & 2014.00 & 2620.67 & 2081.33 & 2238.67 & 2703.00 & 2880.00 & 2857.33 & 2813.44 \\
\hline & $\mathrm{K}_{\text {silicate }}$ & 2345.33 & 6550.33 & 5569.00 & 4821.56 & 2705.67 & 5546.67 & 5974.33 & 4742.22 \\
\hline & Khumate & 2391.00 & 7334.67 & 7350.67 & 5692.11 & 2696.67 & 7097.33 & 7410.33 & 5734.78 \\
\hline \multicolumn{2}{|c|}{ Means } & 2250.11 & 5501.89 & 5000.33 & 4250.78 & 2701.78 & 5174.67 & 5414.00 & 4430.15 \\
\hline \multirow{3}{*}{ I3 } & $\mathrm{K}_{0}$ & 1404.33 & 2516.67 & 2520.00 & 2147.00 & 1310.00 & 2892.00 & 2838.33 & 2346.78 \\
\hline & Ksilicate & 1375.67 & 4043.33 & 4107.00 & 3175.33 & 1663.67 & 6565.67 & 4200.67 & 4143.34 \\
\hline & Khumate & 1483.33 & 4055.00 & 4020.00 & 3186.11 & 1703.33 & 8165.00 & 4093.00 & 4653.78 \\
\hline \multicolumn{2}{|c|}{ Means } & 1421.11 & 3538.33 & 3549.00 & 2836.15 & 1559.00 & 5874.22 & 3710.67 & 3714.63 \\
\hline \multicolumn{2}{|c|}{ Grand mean } & 1969.55 & 4902.85 & 4624.64 & 3065.86 & 2250.65 & 5841.21 & 4814.81 & 4170.58 \\
\hline \multicolumn{10}{|c|}{ Means of Ksource } \\
\hline & $\mathrm{K}_{\mathbf{0}}$ & 1826.44 & 2752.45 & 2540.25 & 2373.05 & 2053.56 & 2736.56 & 2809.44 & 2533.19 \\
\hline & $\mathrm{K}_{\text {silicate }}$ & 1999.44 & 5712.33 & 5078.00 & 4263.26 & 2340.61 & 6702.33 & 5337.22 & 4793.39 \\
\hline & Khumate & 2082.78 & 6243.78 & 6255.67 & 4860.74 & 2357.78 & 8084.74 & 6297.78 & 5580.10 \\
\hline \multicolumn{2}{|c|}{ LSD0.05 } & \multicolumn{4}{|c|}{ 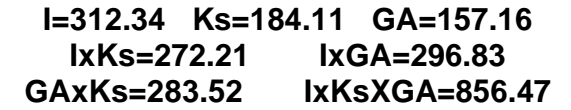 } & \multicolumn{4}{|c|}{ 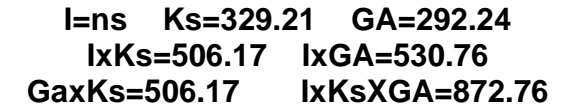 } \\
\hline
\end{tabular}

$\mathrm{I}_{1}, \mathrm{I}_{2}$ and $\mathrm{I}_{3}$ :irrigation at 1.0, 0.8 and 0.6 of $\left(E T_{c}\right), \mathrm{K}_{0}$ :without application, K-humate at rate of $4 \mathrm{~g} \mathrm{~L}^{-1}$,

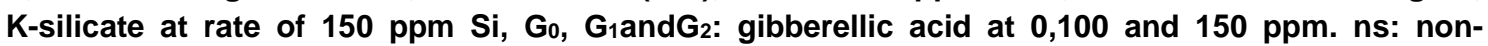
significant at the $5 \%$ levels of probability at L.S.D test. 
Y. M. EL-Edfawy, et al.,

Table 6. Effect of water deficit, $\mathrm{K}$ source and foliar application of gibberellic acid on harvest index, crop index and shelling yieldof maize plant (average of two seasons).

\begin{tabular}{|c|c|c|c|c|c|c|c|c|c|c|c|c|c|}
\hline \multirow{3}{*}{ Irrigation } & \multirow{3}{*}{$\begin{array}{c}\mathrm{K} \\
\text { source }\end{array}$} & \multicolumn{12}{|c|}{ Gibberelic acid } \\
\hline & & $\mathrm{GA}_{0}$ & $\mathrm{GA}_{1}$ & $\mathrm{GA}_{2}$ & Means & $\mathbf{G A}_{0}$ & $\mathbf{G A}_{1}$ & $\mathrm{GA}_{2}$ & Means & $\mathbf{G A}_{0}$ & $\mathbf{G A}_{1}$ & $\mathrm{GA}_{2}$ & Means \\
\hline & & \multicolumn{4}{|c|}{ Harvest index (\%) } & \multicolumn{4}{|c|}{ Crop index (\%) } & \multicolumn{4}{|c|}{ Sheling yield } \\
\hline \multirow{3}{*}{$\mathbf{I}_{1}$} & $\mathrm{~K}_{0}$ & 34.04 & 24.13 & 19.58 & 25.92 & 84.69 & 90.03 & 87.51 & 87.41 & 75.67 & 75.33 & 77.33 & 76.11 \\
\hline & Ksilicate & 20.77 & 79.18 & 37.75 & 45.90 & 90.04 & 92.86 & 93.01 & 91.97 & 79.67 & 85.33 & 76.33 & 80.44 \\
\hline & Khumate & 23.98 & 88.88 & 85.64 & 66.17 & 90.94 & 94.74 & 95.17 & 93.62 & 73.00 & 86.33 & 81.33 & 80.22 \\
\hline \multicolumn{2}{|c|}{ Means } & 26.26 & 64.06 & 47.66 & 45.99 & 88.56 & 92.54 & 91.90 & 91.00 & 76.11 & 82.33 & 78.33 & 78.93 \\
\hline \multirow{3}{*}{$\mathbf{I}_{2}$} & $\mathrm{~K}_{0}$ & 25.49 & 28.81 & 20.34 & 24.88 & 74.07 & 87.71 & 87.33 & 83.04 & 73.67 & 73.33 & 72.00 & 73.00 \\
\hline & Ksilicate & 26.03 & 71.04 & 38.38 & 45.15 & 85.60 & 95.16 & 93.05 & 91.27 & 77.33 & 85.00 & 76.33 & 79.56 \\
\hline & Khumate & 24.74 & 80.16 & 53.91 & 52.94 & 88.16 & 96.57 & 83.33 & 89.35 & 74.67 & 86.67 & 81.33 & 80.89 \\
\hline \multicolumn{2}{|c|}{ Means } & 25.42 & 60.00 & 37.54 & 40.99 & 82.61 & 93.15 & 87.90 & 87.89 & 75.22 & 81.67 & 76.56 & 77.81 \\
\hline \multirow{3}{*}{$I_{3}$} & $\mathrm{~K}_{0}$ & 18.11 & 28.93 & 18.39 & 21.81 & 77.34 & 86.98 & 80.17 & 81.50 & 74.67 & 72.73 & 74.00 & 73.80 \\
\hline & Ksilicate & 16.65 & 65.67 & 36.56 & 39.62 & 83.28 & 93.57 & 89.62 & 88.82 & 75.33 & 83.23 & 75.67 & 78.08 \\
\hline & Khumate & 21.24 & 81.66 & 47.94 & 50.28 & 83.92 & 94.98 & 92.00 & 90.30 & 75.33 & 86.15 & 79.67 & 80.38 \\
\hline \multicolumn{2}{|c|}{ Means } & 18.67 & 58.75 & 34.30 & 37.24 & 81.51 & 91.84 & 87.26 & 86.87 & 75.11 & 80.70 & 76.44 & 77.42 \\
\hline \multicolumn{2}{|c|}{ Grand mean } & 23.45 & 60.94 & 39.83 & 42.38 & 84.23 & 92.51 & 89.02 & 88.66 & 75.48 & 81.57 & 77.11 & 78.63 \\
\hline \multicolumn{14}{|c|}{ Means of Ksource } \\
\hline & $\mathrm{K}_{\mathbf{0}}$ & 25.88 & 27.29 & 19.44 & 24.20 & 78.70 & 88.24 & 85.00 & 83.98 & 74.67 & 73.80 & 74.44 & 74.30 \\
\hline & Ksilicate & 21.15 & 71.96 & 37.56 & 43.56 & 86.31 & 93.86 & 91.89 & 90.69 & 77.44 & 84.52 & 76.11 & 79.36 \\
\hline & Khumate & 23.32 & 83.57 & 62.50 & 56.46 & 87.68 & 95.43 & 90.17 & 91.09 & 74.33 & 86.38 & 80.78 & 80.50 \\
\hline \multicolumn{2}{|c|}{ LSD0.05 } & \multicolumn{4}{|c|}{$\begin{array}{c}\text { I=ns } \quad K S=3.29 \quad \text { GA=2.92 } \\
\text { IXKs=5.06 IXGA=5.31 } \\
\text { GaxKs=8.99 IXKsXGA=8.77 }\end{array}$} & \multicolumn{4}{|c|}{$\begin{array}{cl}\text { I=ns } K S=2.84 & \text { GA=3.45 } \\
\text { IxKs=ns } & \text { IxGA=ns } \\
\text { GaxKs=ns } & \text { IxKsXGA=ns }\end{array}$} & \multicolumn{4}{|c|}{$\begin{array}{cl}\text { I=ns } K s=2.84 & G A=3.45 \\
\text { IxKs=ns } & \text { IxGA=ns } \\
\text { GaxKs=ns } & \text { IxKsXGA=ns }\end{array}$} \\
\hline
\end{tabular}

$\mathrm{I}_{1}, \mathrm{I}_{2}$ and $\mathrm{I}_{3}$ :irrigation at 1.0, 0.8 and 0.6 of $\left(E T_{\mathrm{C}}\right), \mathrm{K}_{0}$ :without application, $\mathrm{K}$-humate at rate of $4 \mathrm{~g} \mathrm{~L}^{-1}$, $\mathrm{K}$-silicate at rate of $150 \mathrm{ppm} \mathrm{Si}, \mathrm{G}_{0}, \mathrm{G}_{1}$ and $\mathrm{G}_{2}$ : gibberellic acid at 0,100 and $150 \mathrm{ppm}$. ns: nonsignificant at the $5 \%$ levels of probability at L.S.D test.

Concerning to double interaction effect between the irrigation levels and foliar spraying of gibberellic acid levels, data indicated that the treatment of $\mathrm{I}_{1}{ }^{*} \mathrm{G} \mathrm{A}_{1}$ gave the highest mean values in all yield characters. These increase were 60.53 , $61.52,59.00,4.30$ and $7.55 \%$ for grain, straw, harvest index, crop index and shelling yield, respectively compared with treatment of $I_{1} * G A_{0}$. Results clarified that gibberellic acid encourage the vegetative growth and increase the efficiency of the plant, increased leaf area and seed weight thereby increasing the yield. These results are in the same line with those obtained by Al-Shaheen and
Awany (2018) and (Mohamed and Ghada 2018).

Also the positive trend was recorded in the interaction effect between irrigation levels and K-sources (K-silicate and K-humate) in all yield characters of maize plant. In addition, the treatment of $\left(\mathrm{I}_{1}{ }^{*} \mathrm{~K}_{\text {humate }}\right)$ gave significant increase in all cases followed by $\left(\mathrm{I}_{2}{ }^{*} \mathrm{~K}\right.$ humate $)$ and there were significant difference between $\left(\mathrm{I}_{2}{ }^{*} \mathrm{~K}\right.$ humate) and $\left(\mathrm{I}_{2}{ }^{*} \mathrm{~K}_{\text {silicate }}\right)$. It may be due to humic acid play an important role in reduction of transpiration and resistance to drought stress by plant. These results are in harmony with those obtained by Ahmed et al. (2017), Al-Shaheen and Awany, (2018) and Qasem et al. (2018) 
who concluded that humic acid and potassium silicate as a foliar application was good practice to increase crop production under sandy soil condition.

As regard to interaction effect between different levels of irrigation, $\mathrm{K}$ sources and gibberellic acid, data in Tables5 and 6 showed that the highest mean values of yield characters were recorded at treatment of $\left(\mathrm{I}_{1} \times \mathrm{K}_{\text {humate }} \times \mathrm{GA}_{1}\right)$ when compared with the other treatments. It worthy to noted that the treatment of $\left(I_{2} \times K_{\text {humate }} \times G_{1}\right)$ in most cases gave a positive increase with nonsignificant difference as compared with treatment of $\left(I_{1} \times K_{\text {humate }} \times G_{1}\right)$. These results are consistent with Qasem et al. (2018) and AI-Shaheen and Ismael (2016) who reported that gibberellic acid and K- sources is an innovative and promising way to reduce the impact of water deficit on pant growth and crop production.

\section{Nutrient uptake}

Results in Tables 7 and 8 showed the main effect of irrigation levels from ETc of maize plant on NPK uptake by both grain and straw. The obtained results clearly indicated a significant influence to full irrigation (100 \% ETc). It was recorded the highest values in NPK uptake by both grain and straw followed by the treatment of $80 \%$ ETc while, the lower one has appeared at $\mathrm{I}_{3}$ (60\% ETc) with a significant decrease from other irrigation treatments.

Table 7. Effect of water deficit, $K$ source and foliar application of gibberellic acid on NPK uptake (kg /ha) by grain of maize plant (average of two seasons).

\begin{tabular}{|c|c|c|c|c|c|c|c|c|c|c|c|c|c|}
\hline \multirow{3}{*}{ Irrigation } & \multirow{3}{*}{$K$ source } & \multicolumn{12}{|c|}{ Gibberelic acid } \\
\hline & & $\mathbf{G A}_{0}$ & $\mathrm{GA}_{1}$ & $\mathrm{GA}_{2}$ & Means & $\mathrm{GA}_{0}$ & $\mathbf{G A}_{1}$ & $\mathrm{GA}_{2}$ & Means & $\mathbf{G A}_{0}$ & $\mathrm{GA}_{1}$ & $\mathrm{GA}_{2}$ & Means \\
\hline & & \multicolumn{4}{|c|}{ 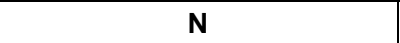 } & \multicolumn{4}{|c|}{$\mathbf{P}$} & \multicolumn{4}{|c|}{ K } \\
\hline \multirow{3}{*}{$\mathbf{I}_{1}$} & $\mathrm{~K}_{0}$ & 16.34 & 20.99 & 15.90 & 17.75 & 6.56 & 10.60 & 6.69 & 7.95 & 11.80 & 15.36 & 9.98 & 12.38 \\
\hline & $\mathrm{K}_{\text {silicate }}$ & 23.36 & 36.24 & 33.52 & 31.04 & 8.64 & 10.72 & 9.20 & 9.52 & 15.68 & 24.96 & 23.04 & 21.23 \\
\hline & $\mathrm{K}_{\text {humate }}$ & 27.60 & 51.92 & 38.32 & 39.28 & 10.10 & 19.36 & 12.24 & 13.90 & 19.20 & 36.00 & 24.56 & 26.59 \\
\hline \multicolumn{2}{|c|}{ Means } & 22.43 & 36.38 & 29.25 & 29.36 & 8.43 & 13.56 & 9.38 & 10.46 & 15.56 & 25.44 & 19.19 & 20.06 \\
\hline \multirow{3}{*}{$I_{2}$} & $\mathrm{~K}_{0}$ & 34.40 & 42.08 & 36.96 & 37.81 & 9.57 & 14.18 & 31.72 & 18.49 & 22.56 & 29.60 & 24.64 & 25.60 \\
\hline & $\mathbf{K}_{\text {silicate }}$ & 42.24 & 73.04 & 47.92 & 54.40 & 15.36 & 26.08 & 20.64 & 20.69 & 27.20 & 54.16 & 27.44 & 36.27 \\
\hline & & 45.36 & 83.92 & 74.80 & 68.03 & 20.51 & 29.12 & 33.52 & 27.72 & 24.48 & 59.04 & 52.80 & 45.44 \\
\hline \multicolumn{2}{|c|}{ Means } & 40.67 & 66.35 & 53.23 & 53.41 & 15.15 & 23.13 & 28.63 & 22.30 & 24.75 & 47.60 & 34.96 & 35.77 \\
\hline \multirow{3}{*}{$\mathrm{I}_{3}$} & $\mathrm{~K}_{0}$ & 40.48 & 37.12 & 50.80 & 58.61 & 15.68 & 13.28 & 24.24 & 23.57 & 22.64 & 22.80 & 27.84 & 24.43 \\
\hline & $\mathbf{K}_{\text {silicate }}$ & 44.24 & 70.08 & 43.52 & 52.61 & 19.44 & 32.48 & 18.88 & 24.53 & 24.16 & 46.16 & 22.08 & 30.80 \\
\hline & $\mathbf{K}_{\text {humate }}$ & 38.56 & 78.88 & 60.88 & 59.44 & 13.36 & 33.36 & 28.64 & 23.47 & 21.92 & 55.92 & 46.88 & 41.57 \\
\hline \multicolumn{2}{|c|}{ Means } & 41.09 & 62.03 & 51.73 & 56.89 & 16.16 & 26.37 & 23.92 & 23.86 & 22.91 & 41.63 & 32.27 & 32.27 \\
\hline \multicolumn{2}{|c|}{ Grand mean } & 34.73 & 54.92 & 44.74 & 56.31 & 13.25 & 21.02 & 20.64 & 23.95 & 21.07 & 38.22 & 28.81 & 34.88 \\
\hline \multicolumn{14}{|c|}{ Means of Ksource } \\
\hline & $\mathrm{K}_{0}$ & 30.41 & 33.40 & 34.55 & 32.79 & 10.60 & 12.69 & 20.88 & 14.72 & 19.00 & 22.59 & 20.82 & 20.80 \\
\hline & $\mathbf{K}_{\text {silicate }}$ & 36.61 & 59.79 & 41.65 & 46.02 & 14.48 & 23.09 & 16.24 & 17.94 & 22.35 & 41.76 & 24.19 & 29.43 \\
\hline & $\mathrm{K}_{\text {humate }}$ & 37.17 & 71.57 & 58.00 & 55.58 & 14.66 & 27.28 & 24.80 & 22.25 & 21.87 & 50.32 & 41.41 & 37.87 \\
\hline \multicolumn{2}{|c|}{ LSD0.05 } & \multicolumn{4}{|c|}{$\begin{array}{llr}I=1.73 & K s=1.24 & G A=0.95 \\
\text { IxKs=1.65 } & \text { IXGA }=1.99 \\
\text { GaxKs=2.18 IxKsXGA=2.86 }\end{array}$} & \multicolumn{4}{|c|}{$\begin{array}{|lrr|}I=2.43 & \text { Ks }=0.98 & \text { GA }=1.49 \\
\text { IxKs=2.59 } & \text { IXGA }=1.58 \\
\text { GaxKs=3.07 IxKsXGA=4.48 }\end{array}$} & \multicolumn{4}{|c|}{$\begin{array}{lll}I=2.04 \quad K s=1.07 \quad G A=1.11 \\
I X K s=1.92 & \text { IXGA }=1.73 \\
\text { GaxKs }=2.58 & \text { IxKs XXA }=3.33\end{array}$} \\
\hline
\end{tabular}

$\mathrm{I}_{1}, \mathrm{I}_{2}$ and $\mathrm{I}_{3}$ : irrigation at 1.0, 0.8 and 0.6 of $\left(E T_{c}\right), \mathrm{K}_{0}$ : without application, $\mathrm{K}$-humate at rate of $4 \mathrm{~g} \mathrm{~L}^{-1}$, $\mathrm{K}$-silicate at rate of $150 \mathrm{ppm} \mathrm{Si,} \mathrm{G}_{0}, \mathrm{G}_{1}$ and $\mathrm{G}_{2}$ : gibberellic acid at 0,100 and $150 \mathrm{ppm}$. ns: nonsignificant at the $5 \%$ levels of probability at L.S.D test. 
Y. M. EL-Edfawy, et al.,

Table 8. Effect of water deficit, $\mathrm{K}$ source and foliar application of gibberellic acid on NPK Uptake ( $\mathrm{kg} / \mathrm{ha}$ ) by straw of maize plant (average of two seasons).

\begin{tabular}{|c|c|c|c|c|c|c|c|c|c|c|c|c|c|}
\hline \multirow{3}{*}{ Irrigation } & \multirow{3}{*}{ K source } & \multicolumn{12}{|c|}{ Gibberellic acid } \\
\hline & & $\mathrm{GA}_{0}$ & $\mathrm{GA}_{1}$ & $\mathrm{GA}_{2}$ & Means & $\mathbf{G A}_{0}$ & $\mathbf{G A}_{1}$ & $\mathrm{GA}_{2}$ & Means & $\mathbf{G A}_{0}$ & $\mathrm{GA}_{1}$ & $\mathrm{GA}_{2}$ & Means \\
\hline & & \multicolumn{4}{|c|}{$\mathbf{N}$} & \multicolumn{4}{|c|}{$\mathbf{P}$} & \multicolumn{4}{|c|}{$\mathbf{K}$} \\
\hline \multirow{3}{*}{$\mathbf{I}_{\mathbf{1}}$} & $\mathrm{K}_{\mathbf{0}}$ & 22.88 & 27.44 & 20.18 & 23.50 & 18.94 & 22.57 & 15.62 & 19.05 & 18.94 & 22.57 & 15.62 & 19.05 \\
\hline & Silicate & 22.88 & 35.76 & 26.00 & 28.21 & 18.14 & 29.04 & 20.83 & 22.67 & 18.14 & 29.04 & 20.83 & 22.67 \\
\hline & Khumate & 26.72 & 43.04 & 41.20 & 36.99 & 21.14 & 32.64 & 30.64 & 28.14 & 21.14 & 32.64 & 30.64 & 28.14 \\
\hline \multicolumn{2}{|c|}{ Means } & 24.16 & 35.41 & 29.13 & 29.57 & 19.41 & 28.08 & 22.37 & 23.28 & 19.41 & 28.08 & 22.37 & 23.28 \\
\hline \multirow{3}{*}{$\mathbf{I}_{2}$} & $\mathrm{~K}_{0}$ & 25.52 & 22.24 & 25.92 & 24.56 & 11.68 & 9.82 & 13.46 & 11.66 & 20.58 & 16.50 & 20.37 & 19.15 \\
\hline & Silicate & 23.36 & 35.36 & 24.16 & 27.63 & 11.04 & 17.25 & 10.28 & 12.86 & 19.34 & 27.46 & 18.29 & 21.69 \\
\hline & $K_{\text {humate }}$ & 21.92 & 43.28 & 36.16 & 33.79 & 7.74 & 18.98 & 14.38 & 13.70 & 14.88 & 29.47 & 26.64 & 23.66 \\
\hline \multicolumn{2}{|c|}{ Means } & 23.60 & 33.63 & 28.75 & 28.66 & 10.15 & 15.35 & 12.71 & 12.74 & 18.26 & 24.48 & 21.77 & 21.50 \\
\hline \multirow{3}{*}{$I_{3}$} & $\mathrm{~K}_{0}$ & 8.96 & 10.88 & 9.12 & 9.65 & 1.19 & 3.92 & 3.44 & 2.85 & 5.50 & 8.18 & 7.28 & 6.98 \\
\hline & Silicate & 12.98 & 20.69 & 17.80 & 17.16 & 5.96 & 8.87 & 7.59 & 7.47 & 9.84 & 16.98 & 15.12 & 13.98 \\
\hline & Khumate & 12.69 & 32.68 & 25.92 & 23.76 & 5.74 & 15.98 & 12.28 & 11.33 & 10.18 & 26.64 & 21.29 & 19.37 \\
\hline \multicolumn{2}{|c|}{ Means } & 11.54 & 21.42 & 17.61 & 16.86 & 4.30 & 9.59 & 7.77 & 7.22 & 8.50 & 17.27 & 14.56 & 13.44 \\
\hline \multicolumn{2}{|c|}{ Grand mean } & 19.77 & 30.15 & 25.16 & 19.26 & 11.29 & 17.68 & 14.28 & 14.41 & 15.39 & 23.28 & 19.56 & 19.41 \\
\hline \multicolumn{14}{|c|}{ Means of K-source } \\
\hline & $\mathrm{K}_{0}$ & 19.12 & 20.19 & 18.41 & 19.24 & 10.61 & 12.10 & 10.84 & 11.18 & 15.01 & 15.75 & 14.42 & 15.06 \\
\hline & Silicate & 19.74 & 30.60 & 22.65 & 24.33 & 11.71 & 18.39 & 12.90 & 14.33 & 15.77 & 24.49 & 18.08 & 19.45 \\
\hline & Khumate & 20.44 & 39.67 & 34.43 & 31.51 & 11.54 & 22.54 & 19.10 & 17.73 & 15.40 & 29.58 & 26.19 & 23.72 \\
\hline \multicolumn{2}{|c|}{ LSD0.05 } & \multicolumn{4}{|c|}{$\begin{array}{c}\mathrm{I}=2.20 \mathrm{Ks}=1.72 \mathrm{GA}=1.186 \\
\text { IXKs=ns IXGA=ns } \\
\text { GAxKs=2.78 IXKsXGA=3.56 }\end{array}$} & \multicolumn{4}{|c|}{$\begin{array}{c}\mathrm{I}=1.39 \mathrm{Ks}=1.13 \mathrm{GA}=0.82 \\
\text { IXKs=1.42 IXGA=ns } \\
\text { GAXKs=1.75 IXKsXGA=2.47 }\end{array}$} & \multicolumn{4}{|c|}{$\begin{array}{c}\mathrm{I}=1.96 \mathrm{Ks}=1.20 \mathrm{GA}=1.011 \\
\text { IXKs= } 1.75 \quad \text { IXGA }=1.94 \\
\text { GAXKs=2.48 IxKsXGA=3.03 }\end{array}$} \\
\hline
\end{tabular}

$I_{1}, I_{2}$ and $I_{3}$ : irrigation at 1.0, 0.8 and 0.6 of $\left(E T_{C}\right), K_{0}$ : without application, $K$-humate at rate of $4 \mathrm{~g} \mathrm{~L}^{-1}$, $\mathrm{K}$-silicate at rate of $150 \mathrm{ppm} \mathrm{Si}, \mathrm{G}_{0}, \mathrm{G}_{1}$ and $\mathrm{G}_{2}$ : gibberellic acid at 0,100 and $150 \mathrm{ppm}$. ns: nonsignificant at the $5 \%$ levels of probability at L.S.D test.

Also data in the Tables $(7$ and 8$)$ showed that the foliar spraying of the different levels of gibberellic acid gave significant effect on NPK uptake in both grain and straw of maize plant particularly at rate of $100 \mathrm{mg} \mathrm{L}^{-1}\left(\mathrm{GA}_{1}\right)$ compared with other treatments.

Regarding to the effect of K-source application on NPK uptake ( $\mathrm{kg} / \mathrm{ha}$ ) by grain and straw for maize plant, data indicate that NPK uptake were affected in increasing trend by spraying $\mathrm{K}$-silicate and K-humate compared with the control. Moreover, using treatment of K-humate in all cases gave higher values than $K$ silicate with a significant difference between them. These results in harmony with those obtained by Ahmed et al. (2017) and El-Edfawy (2017).

Concerning to the interaction effect between different levels of irrigation and gibberellic acid on NPK uptake, the obtained results showed that application of foliar gibberellic acid at any rate with different level of irrigation gave higher NPK uptake in both grain and straw of maize plant compared with $\mathrm{GA}_{0}$. The highest values of NPK uptake were obtained by treatment of $\mathrm{I}_{1}{ }^{*} \mathrm{GA}_{1}$ and there were a significant difference as compared with other treatments. 
As regard to interaction effect between irrigation level and $\mathrm{K}$-source, results in the same tables clearly showed a positive and significant effect on NPK uptake by grain and straw of maize plant. It worthy to noted that, the treatments of $\mathrm{I}_{2}{ }^{*} \mathrm{~K}_{\text {silicate }}$ and $\mathrm{I}_{2}{ }^{*} \mathrm{~K}_{\text {humate }}$ gave the higher mean values in NPK uptake in both grain and straw and there were a significant difference between them. In addition spraying by K-humate gave values better than spraying by K-silicate at any level of irrigation.

Regarding to the interaction effect between irrigation rates, K-source and gibberellic acid on NPK uptake (kg/ha) the results indicated that, the treatment of $I_{1}{ }^{*} K_{\text {humate }}{ }^{*} G_{1}$ gave the highest values of NPK uptake by both grain and straw of maize plant. Similar results were obtained by Al-Shaheen and Ismael (2016); Ahmed et al. (2017); El-Edfawy (2017) and Qasem et al. (2018).

\section{Water use efficiency:}

Water use efficiency (WUE) in $\mathrm{kg} / \mathrm{m}^{3}$ was calculated for the deferent treatments, using the following form formulae of Vites (1965):

$$
\text { W.U.E = - }
$$

Fig.1. represent the obtained results of water use efficiency (W.U.E.) for maize crop expressed as kg grain yield per one cubic meter of water consumed irrigation water, which was affected by irrigation regime and $\mathrm{K}$-silicate or $\mathrm{K}$ - humate companied 9as well as applying various rates of gibberellic acid during 2019 and 2020 summer seasons. The results go hand in hand with those obtained for maize grain yield. Similar results were found by El-Hendawy et al. (2008). However, it should be stated that the highest W.U.E. value, 1.38 was obtained for $80 \% \mathrm{ET}_{\mathrm{c}}$ and $\mathrm{K}$ - humate at $\mathbf{5 0} \mathrm{mg} \mathrm{L}^{-1}$ concentration of gibberellic acid. This W.U.E. value is agreement with that reported by Goring et al. (1998) and Miceli et al. (2019) who stated that the increase of stomatal conductance due to gibberellic acid has been related to the higher accumulation of carbohydrates and potassium in guard cells of treated plants, that may influence speed and degree of stomata opening Even if the higher stomatal conductance of treated plants determines an increase of transpiration rates and water consumption, it also promotes gas exchange and photosynthetic $\mathrm{CO}_{2}$ assimilation, thus increasing dry matter accumulation and WUE.

\section{Soil content of available NPK}

Results in Table 9 showed that the main effect of irrigation levels, K-silicate, $\mathrm{K}$-humate and gibberellic acid on soil available $N, P$ and $K$. The obtained results showed that the soil available $\mathrm{N}$ was significantly increased with the foliar spraying of the K-silicate, K-humate and the different levels of gibberellic acid, but not significantly affected by irrigation levels. The increasing percentages in soil available $\mathrm{N}$ due to $\mathrm{K}$-silicate and $\mathrm{K}$ humate application were 4.24 and $7.70 \%$ respectively as compared with $K_{0}$ whereas, treatments of $G_{1}$ and $G_{2}$ recorded 6.71 and 3.80 , respectively as compared with $\mathbf{G}_{0}$. This irrigation requirement with $\mathrm{K}$-humate and $\mathrm{K}$-silicate caused positive effect on nitrogen movement and it's has been positive effect on moisture, nutrient contents and as results available nitrogen. These results are in the same line with those obtained by Recep (2004) and Yalmz (2007). 


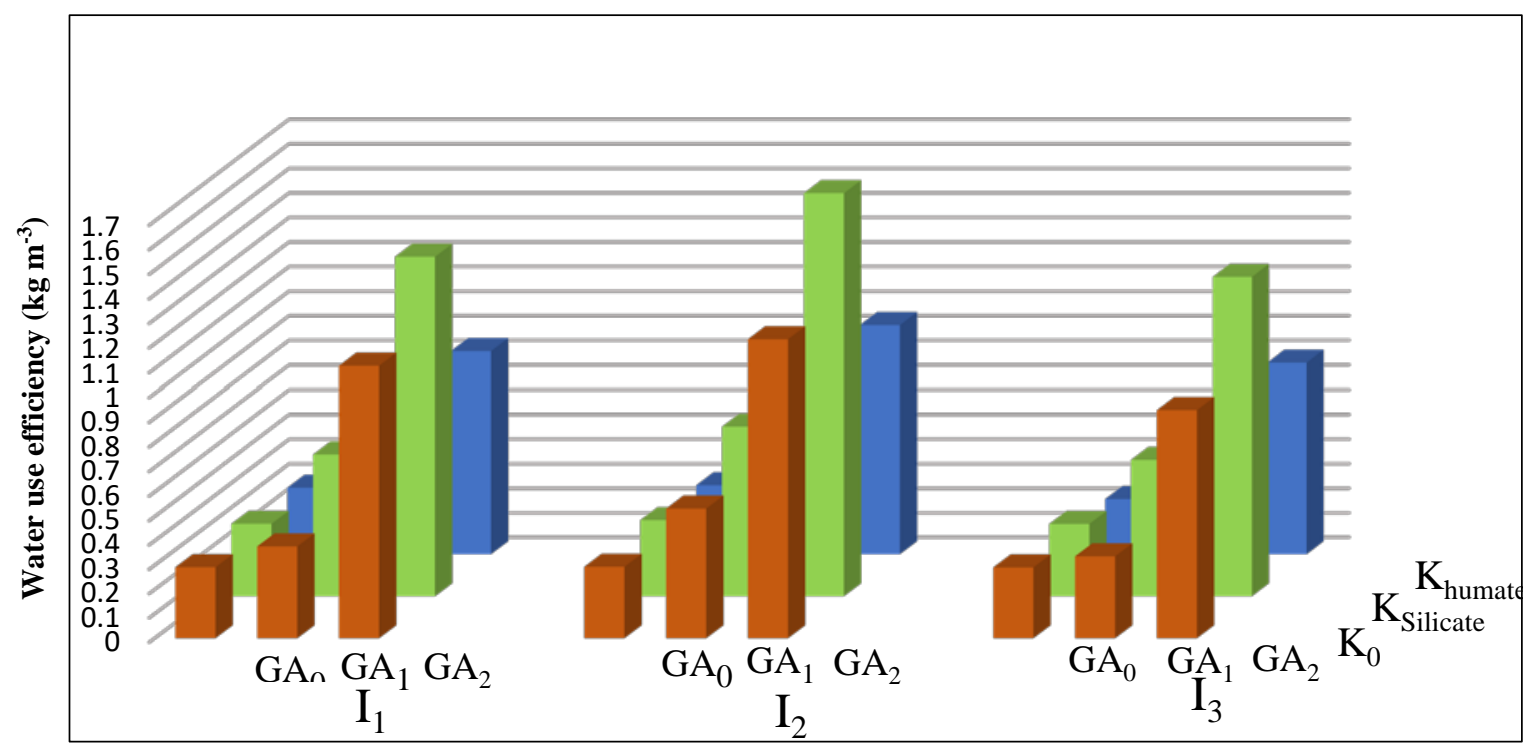

Fig. 1. Water use efficiency as affected by $\mathrm{K}$ sources, foliar application of gibberellic acid andirrigation levels.

Table 9. Effect of water deficit, $\mathrm{K}$ source and foliar application of gibberellic acid on available NPK ( $\mathrm{mg} \mathrm{kg}^{-1}$ ) in soil (average of two seasons).

\begin{tabular}{|c|c|c|c|c|c|c|c|c|c|c|c|c|c|}
\hline \multirow{3}{*}{ Irrigation } & \multirow{3}{*}{ K source } & \multicolumn{12}{|c|}{ Gibberelic acid } \\
\hline & & $\mathbf{G A}_{0}$ & $\mathrm{GA}_{1}$ & $\mathrm{GA}_{2}$ & Means & $\mathbf{G A}_{0}$ & $\mathbf{G A}_{1}$ & $\mathbf{G A}_{2}$ & Means & $\mathbf{G A}_{0}$ & $\mathrm{GA}_{1}$ & $\mathbf{G A}_{2}$ & Means \\
\hline & & \multicolumn{4}{|c|}{$\mathbf{N}$} & \multicolumn{4}{|c|}{$\mathbf{P}$} & \multicolumn{4}{|c|}{$\mathrm{K}$} \\
\hline \multirow{3}{*}{$\mathbf{I}_{1}$} & $\mathrm{~K}_{0}$ & 26.70 & 30.03 & 23.10 & 26.61 & 5.30 & 8.41 & 5.32 & 6.34 & 54.00 & 57.00 & 50.07 & 53.69 \\
\hline & Ksilicate & 30.47 & 26.40 & 28.97 & 28.61 & 8.89 & 6.13 & 8.20 & 7.74 & 54.00 & 56.00 & 50.07 & 53.36 \\
\hline & K humate & 24.63 & 27.70 & 32.10 & 28.14 & 5.49 & 6.83 & 9.84 & 7.39 & 54.50 & 57.67 & 49.97 & 54.04 \\
\hline \multicolumn{2}{|c|}{ Means } & 27.27 & 28.04 & 28.06 & 27.79 & 6.56 & 7.13 & 7.79 & 7.16 & 54.17 & 56.89 & 50.03 & 53.70 \\
\hline \multirow{3}{*}{$I_{2}$} & $\mathrm{~K}_{\mathbf{0}}$ & 28.07 & 27.70 & 26.30 & 27.36 & 7.70 & 5.36 & 5.41 & 6.16 & 48.07 & 50.93 & 46.10 & 48.37 \\
\hline & $\mathrm{K}_{\text {silicate }}$ & 24.47 & 31.13 & 23.97 & 26.52 & 5.25 & 8.96 & 6.40 & 6.87 & 53.10 & 50.13 & 56.13 & 53.12 \\
\hline & Khumate & 25.67 & 31.33 & 27.17 & 28.06 & 6.07 & 8.21 & 5.52 & 6.60 & 53.40 & 50.10 & 61.77 & 55.09 \\
\hline \multicolumn{2}{|c|}{ Means } & 26.07 & 30.06 & 25.81 & 27.31 & 6.34 & 7.51 & 5.78 & 6.54 & 51.52 & 50.39 & 54.67 & 52.19 \\
\hline \multirow{3}{*}{$I_{3}$} & $\mathrm{~K}_{0}$ & 22.57 & 23.07 & 26.13 & 23.92 & 3.23 & 4.52 & 5.10 & 4.28 & 43.17 & 44.03 & 46.07 & 44.42 \\
\hline & $\mathrm{K}_{\text {silicate }}$ & 22.00 & 29.07 & 27.07 & 26.04 & 5.53 & 6.47 & 5.30 & 5.77 & 49.07 & 44.00 & 53.03 & 48.70 \\
\hline & Kumate & 30.17 & 24.07 & 28.80 & 27.68 & 8.21 & 5.43 & 6.57 & 6.74 & 51.53 & 51.00 & 48.10 & 50.21 \\
\hline \multicolumn{2}{|c|}{ Means } & 24.91 & 25.40 & 27.33 & 25.88 & 5.66 & 5.47 & 5.66 & 5.60 & 47.92 & 46.34 & 49.07 & 47.78 \\
\hline \multicolumn{2}{|c|}{ Grand mean } & 26.08 & 27.83 & 27.07 & 26.99 & 6.19 & 6.70 & 6.41 & 6.43 & 51.20 & 51.21 & 51.26 & 51.22 \\
\hline \multicolumn{14}{|c|}{ Means of Ksource } \\
\hline & $\mathrm{K}_{0}$ & 25.78 & 26.93 & 25.18 & 25.96 & 5.41 & 6.10 & 5.28 & 5.60 & 48.41 & 50.66 & 47.41 & 48.83 \\
\hline & Ksilicate & 25.64 & 28.87 & 26.67 & 27.06 & 6.56 & 7.19 & 6.63 & 6.79 & 52.06 & 50.04 & 53.08 & 51.73 \\
\hline & Khumate & 26.82 & 27.70 & 29.36 & 27.96 & 6.59 & 6.83 & 7.31 & 6.91 & 53.14 & 52.92 & 53.28 & 53.11 \\
\hline \multicolumn{2}{|c|}{ LSD0.05 } & \multicolumn{4}{|c|}{$\begin{array}{c}\text { I=ns } \quad K s=1.18 \quad \text { GA=0.85 } \\
\text { IXKs=ns IXGA=1.04 } \\
\text { GAXKs=2.01 IxKsXGA=1.52 }\end{array}$} & \multicolumn{4}{|c|}{$\begin{array}{c}\text { I=ns Ks=ns GA=ns } \\
\text { IxKs=ns IXGA=ns } \\
\text { GaxKs=ns IxKsXGA=ns }\end{array}$} & \multicolumn{4}{|c|}{$\begin{array}{cll}\mathrm{I}=1.24 & \mathrm{Ks}=1.47 \quad \mathrm{GA}=\mathrm{ns} \\
\mathrm{IXKs}=2.42 & \text { IXGA=2.37 } \\
\text { GaxKs }=\text { ns } & \text { IXKs XKA=ns }\end{array}$} \\
\hline
\end{tabular}

$\mathrm{I}_{1}, \mathrm{I}_{2}$ and $\mathrm{I}_{3}$ : irrigation at 1.0, 0.8 and 0.6 of $\left(E T_{c}\right), \mathrm{K}_{0}$ : without application, $\mathrm{K}$-humate at rate of $4 \mathrm{~g} \mathrm{~L}^{-1}$,

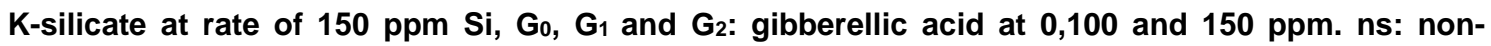
significant at the $5 \%$ levels of probability at L.S.D test. 
Data in the same table also indicated that soil available $P$ was not significantly affected by different treatments while, soil available $\mathrm{K}$ was significantly affected by irrigation level, K-silicate and $\mathrm{K}$ humate but not significantly affected by the different levels of gibberellic acid. $\mathrm{K}$ humate and K-silicate increased availability of $\mathrm{P}$, but increased soil $\mathrm{pH}$ which negative effect on increased $P$ availability may be caused the soil available $P$ was not significant. These results are in the same line with those obtained by Zhongqi et al. (2011) and Dongfeng et al. (2016). Potassium affected by K-silicate and K-humate which reduce the negative effects of water deficit and increased $\mathrm{K}$ movements but $\mathrm{K}$ not response by gibberellic acid. These results are agreement with with that reported by Camargo et al. (2014) and Ismail et al. (2017).

As regard to interaction effect the data clearly showed a positive effect of the treatments of $\mathrm{I}_{2}{ }^{*} \mathrm{~K}_{\text {humate }} * \mathrm{GA}_{1}$ compared with the other treatments. These results are in harmony with those obtained by Camargo et al. (2014), Al-Shaheen and Ismael (2016), Ismail et al. (2017), EIEdfawy (2017) and Qasem et al. (2018).

From these results it could be concluded that using foliar application of gibberellic acid at $100 \mathrm{mg} \mathrm{L}^{-1}$ and Khumate at rate of $400 \mathrm{mg} \mathrm{L}^{-1}$ can reduce $15 \%$ from total amount of water irrigation required to maize plant in sandy soil.

\section{Conclusion}

From the previous discussion it can be concluded that application ofKhumate at rate of $4 \mathrm{~g} \mathrm{~L}^{-1}$ in combination with gibberellic acid at $100 \mathrm{mg} \mathrm{L}^{-1}$ under $80 \%$ from ETc significantly increased grain yield, yield parameter and NPK uptake by maize plant which increased plant resistant to drought stress. It can reduce $20 \%$ from total amount of water irrigation required to maize plant in sandy soil. Soil available $P$ was not significantly affected by different treatments while, soil available $\mathrm{K}$ was significantly affected by irrigation level, K-silicate and K-humate but not significantly affected by the different levels of gibberellic acid.

\section{REFERENCES}

Abd-All, A., A. Elnamas and E. El-Nagger (2017). Effect of humic acid and foliar application of different potassium sources on yield, quality and water use efficiency of sweet potatoes grown under drip irrigation sandy soil. Alex. Sci. Exch. 38:543-553.

Abd El-moneim, E.A.A., M.M.M. Abd El Migeed and M.M. Ismail (2007). Zinc sprays for improving yield and fruit quality of Washington Navel Orange Trees Grown under Sandy soil conditions. Research Journal of Agriculture and Biological Sciences, 3 (5): 498-503.

Abd-Elaziz, S.A., A.A. Alkharpotly, M.M. Yousry and A.I.A. Abido (2019). Effect of foliar application with salicylic acid and potassium silicate on squash plants (Cucurbita pepo L.) yield and quality. Fayoum J. Agric. Res. And Development, 33 (1): 1-29.

Abdel-Rahman, M.M. (2017). Effect of humic and fulvic substances and moringa leaf extract on sudan grass plants grown under saline conditions. Can. J. Soil Sci. 97: 703-716.

Ahmed, E. A., A.E. El-Namas and E.A. ElNaggar (2017). Effect of humic acid and foliar application of different potassium sources on yield, quality and water use efficiency of sweet potato grown under drip irrigation in sandy soil. Alex. Sci. Exc. J. 38 (3): 543-553.

Allen, R. G., L. S. Pereira, D. Raes and M. Smith (1998).

Crop 
evapotranspiration: Guidelines for computing crop water requirements. FAO. Irrigation and Drainage Paper 56. Rome: Food and Agriculture

Al-Shaheen, M. R. and S. Awany (2018). The effect of water deficit and gibberellic acid on growth productivity of corn (Zea mays L.), J. of Adv. Res. Agric Sci. Tech. 1 (1\&2): 52-56.

AI-Shaheen, M.R. and H.M. Ismael (2016). The interactive effect of water deficiency, gibberellic acid and proline on the growth of maize. J. of Plant Enviro. Res. 1(1): 0018-0023.

Arkadiusz, A. (2018). Effect of silicon fertilization on crop yield quantity and quality-A literature review in Europe. J. Plants, 7 (54): 1-17.

Asgharipour, M.R. and H. Mosapour (2016). A foliar application of silicon enhances drought tolerance in fennel. J. Anim. Plant Sci., 26(4): 1056-1062.

Atta, Y. I. M. (2014). Improving growth, yield and water productivity of some maize cultivars by new planting method. Innovative Water Management Award Winning, 1-12.

Camargo, M.S., B.K.L. Bezerra, A.C. Vitti, M.A. Silva and A.L. Oliveira (2017). Silicon fertilization reduces the deleterious effects of water deficit in sugarcane. Journal of Soil Science and Plant Nutrition, 17 (1): 99-111.

Camargo, M.S., G.H. Korndörfer and P. Wyler (2014). Silicate fertilization of sugarcane cultivated in tropical soils. Field Crops Res., 167: 64-75.

Cumagun, C.J.R. and M.R. Moosavi (2015) Significance of Biocontrol Agents of Phytonematodes. In: Askary TH, Martinelli PRP (eds) Biocontrol agents of phytonematodes. CABI, Wallingford, pp 50-78.

Dongfeng, H., A. Limin Wang and B. C. Tao Luo (2016). Effects of Applying Humic Fertilizers on Tea's Yield,
Nutritional Quality and Soil Fertility in a Tea Garden 3rd International Conference on Materials Engineering, Manufacturing Technology and Control, 1046- 1051. The authors Published by Atlantis Press.

Doorenbos, J. and A.H. Kassam (1979). Yield response to water. FAO Irrig. and Drain. Paper No. 33, FAO, Rome, Italy. 193 pp.

El-Bassiony, A.M., Z. F. Fawzy, M. M. H. Abd El-Baky and Mohamoud (2010). Response of snap bean plants to mineral fertilizers and humic acid application. Res. J. of Agric. And Bio. Sci. 6 (2): 169-175.

El-Edfawy, Y. M. (2017). Effect of NPKfertilizer and humic acid applications on yield and quality of canola plant (Brassica napus L.) grown in sandy soil. Nat. and Sci. 15 (12): 205-211.

El-Hendawy, S. E., E.A. Abd El-Lattief, M. S. Ahmed and U. Schmidhalter (2008). Irrigation rate and plant density effects on yield and water use efficiency of drip-irrigated corn. Agricultural Water Management 95 (7): 836-844.

El-Shraiy, A.M. and A. M. Hegazi (2009). Effect of acetylsalicylic acid, indole-3bytric acid and gibberellic acid on plant growth and yield of pea (Pisum Sativum L). Australian Journal of Basic and Applied Sciences, 3 (4): 3514-3523.

Ewis, M. M., K. M. Abd El-Latif and M. I. Badawi (2016). Response of Maize (Zea mays L.) to Moisture Stress under Different Nitrogen Fertilization Levels. J. Soil Sci. and Agric. Eng., Mansoura Univ., 7 (11): 865 - 872.

Goring, H., S. Koshuchowa and C. Deckert (1998). Influence of gibberellic acid on stomatal movement. Bioche. Physiol. Pflanz. 186: 367-374

Harshad, T., K. Bhanu, Y. Yogesh and S. Sudhakar (2018). Impact of humic + 
fulvic acid and chemical fertilizer application on plant growth and yield traits of sunflower (Helianthus annuus L.) under alfisols Journal of Pharmacognosy and Phytochemistry, SP1: 2992-2994.

Henk-Maarten Laane (2018). The Effects of Foliar Sprays with Different

Hussein, K. and A. Hassan (2011). Effect of different levels of humic acids on the nutrient content, plant growth, and soil properties under conditions of salinity Soil \& Water Res., 6(1): 21-29.

Ismail, E. E. M., R. M. Galal and M. E. Mahseb (2017). Effect of some potassium sources on productivity and quality of pea under conditions of saline soil J. Plant Production, Mansoura Univ., 8 (12): 1323 - 1328.

Jackson, M. L. (1973). Soil Chemical Analysis. Prentice-Hall, Englewood Cliffs, N. J. Library of Congress, USA.

Jamala G. and D. Oke (2013). Humic Substances and Mineral-associated soil organic carbon as influenced by land use in southeastern Adamawa State, Nigeria. Journal of Environmental Science, Toxicology and Food Technology 6(5): 59-70.

Jawahar, S., C. Kalaiyarasan, M.V. Sriramachandrasekharan; N. Jain and M. Naveenkumar (2017). Effect of orthosilicic acid formula on growth and yield of maize in different soils. In Proceedings of the 7th International Conference on Silicon in Argriculture, Bengaluru, India, 24-28 October; p. 132.

Klute, A. (1986). "Methods of soil analysis part I. physical and mineralogical methods". 2nd ed., Agro. Madison, Wisconsin, U.S.A.

Larcher, W. (2003). Physiological Plant Ecology: Ecophysiology and Stress Physiology of Functional Groups, 4th. Edition, Springer, New York.
Mauricio, A., C. Filho, E. H. Colebrook, D. P. A. Lloyd, C. P. Webster, S. J. Mooney, A. L. Phillips, P. Hedden and W. R. Whalley (2013). The involvement of gibberellin signalling in the effect of soil resistance to root penetration on leaf elongation and tiller number in wheat. Plant Soil. 371:81-94

Meena, V.D., M. L. Dotaniya, V. Coumar, S. Rajendiran, A.S. Kundu and A. Subba, R. (2014). A case for silicon fertilization to improve crop yields in tropical soils. Proc. Natl. Acad. Sci., India, Sect. Biol. Sci. (July-Sept 2014) 84 (3): 505-518.

Mensah, B. (1997). Soil water management implications during the constant rate and the falling rate stages of soil evaporation. Agriculture Water Management 33 (2-3): 87-97.

Miceli, A., A. Moncada, L. Sabatino and F. Vetrano (2019). Effect of gibberellic acid on growth, yield, and quality of leaf lettuce and rocket grown in a floating system. Agronomy 9(7): 382404.

Mohamed, M.H. and A.M. Ghada (2018). Microbial gibberellic acid impact on zeamayz (L.) plants under levels of water salinity. Egy. J. Soil. Sci. 58 (3): 373-382.

Mukhtar, A., F. Hassen and Y. Khurshid (2011). Does silicon and irrigation have impact on drought tolerance mechanism of sorghum? Agricultural Water Management 98: 1808- 1812.

Nasir Khan, M., M. H. Siddiqui, M. M. A. Khan, M. Naeem and F. Mohammad (2012). Calcium chloride and gibberellic acid protect linseed (Linum usitatissimum L.) from $\mathrm{NaCl}$ stress by inducing antioxidative defence system and osmoprotectant accumulation. Acta Physiol Plant 32: 121-132.

Olsen, S. R., C.V. Cole, F.S. Watanabe and L.A. Dean (1954). Estimation of available phosphorous in soil by 
extraction with sodium bicarbonate. U.S. dept. Agric. Cir. 939.

Ouda, S., K. Abd El-Latif and F. Khalil (2018). Water requirements for major crops. Chapter 2, pp. 25-32. In Major Crops and Water Requirements in Egypt Irrigation Water Mangement Under Changing Climate. July 2018. ISBN: 978-3-319-21770-3.

Page, A. L., R. H. Miller and D. R. Keeny (1982). "Methods of Soil Analysis Part II: chemical and microbiological properties. $2^{\text {nd }}$ Ed. Am. Soc. Agro. Madison, Wisconsin, U.S.A.

Qasim, A., S.M. Khan, A. Khan, I. Hussian, A. Zahoor and M. A. Khan (2018). Effect of gibberellic acid and potassium silicate on physiological growth of okra (Abelmoschus esculentus L.) under salinity stress Pure and Appl. Bio., 7 (1): 8-9.

Ratnayake, R.M.R.N.K., W.A.M. Daundasekera, H.M. Ariyarathne and M.Y.U. Ganehenege (2016). Soil application of potassium silicate reduces the intensity of downy mildew in bitter gourd (Momordica charantia L.) leaves. Ceylon Journal of Science, 45 (1): 23-31.

Recep, C. (2004). Effect of water stress at different development stages on vegetative and reproductive growth of corn. Field Crops Research, 89: 1-16.

Rose, M., A. Patti, K. Little, A. Brown, W. Jackson and T. Cavagnaro (2014). A metaanalysis and review of plantgrowth response to humic substances: practical implications for agriculture D.S. Sparks (Ed.). Ad Agro 124: 37-89. Silicon Compounds. Plants (7) 45: 1 - 22.

Soratto, R.P., C.A.C. Crusciol, G.S.A. Castro, C.H.M. Costa and J.F. Neto
(2012). Leaf applications of salicylic acid to white oat and wheat. Rev. Bras. Cienc. Solo, 36: 1538-1544.

Sumera, A. K., M. Hamayun, H. Kim, H. Yoon, I. Lee and J. Kim (2009). Gibberellin production and plant growth promotion by a newly isolated strain of Gliomastix murorum. World J Microbiol Biotechnol 25: 829-833.

Tanimoto, E. (2012). Tall or short? Slender or thick? A plant strategy for regulating elongation growth of roots by low concentrations of gibberellin. Ann. Bot., 110: 373-381.

Vites, F.G. (1965). Increasing water use efficiency by soil management in plant environment and efficient water use. J. American Soc. Agron., 26: 537-546.

Walsh, O., J. Mc Clintic-Chess and B. Steven (2017). Rate and application time of plant silicon on winter wheat yield and quality. In Proceedings of the $7^{\text {th }}$ International Conference on Silicon in Agriculture, Bengaluru, India, 24-28 October; p. 148.

YImaz, C. (2007). Hümikvefülvikasit, Hasad Bitkisel Üretim, Ocak, 260: 74.

Zhang, M. and Z. He (2004). Long-term changes in organic carbon and nutrients of an Ultisol under rice cropping in southeast China. Geoderma, 118: 167.179

Zhongqi, H., C. Daniel, B. Olk and J. Cade-Menun (2011). Forms and lability of phosphorus in humic acid fractions of horde silt loam soil SSSAJ: 75(5): September-October, 1712- 1722.

Zyada, H. G. and E. A. Bardisi (2018). Effect of potassium application methods on garlic plants grown under sandy soil condition. Zagazig J. Agric. Res., 45 (6A): 1941. 
تأثير مصادر البوتاسيوم مع حمض الجبريلين على انتاجية نبات الذرة الثامية تحت الإجهاد المائى فى الأراضى الرملية

$$
\begin{aligned}
& \text { ياسر محمد الإدفاوى، محمد سعد محمد على، السيد محمد على بلى } \\
& \text { مركز البحوث الززاعية - معهُ بحوث الأراضى والمياه والبيئة - الجيزة }
\end{aligned}
$$

الملخص العبى

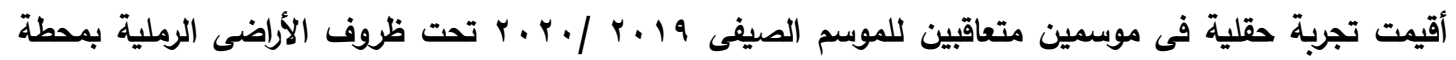

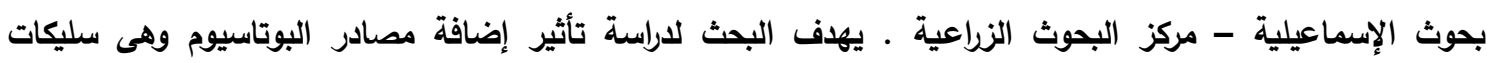

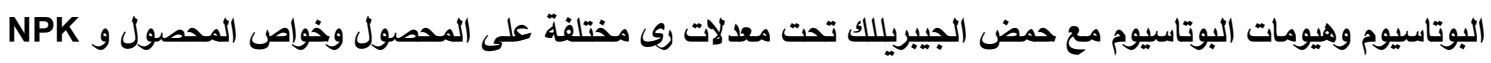

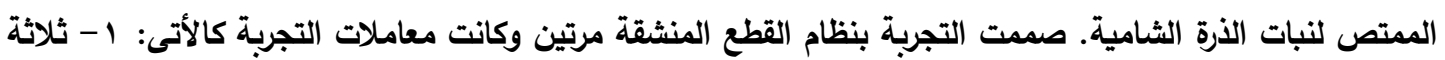

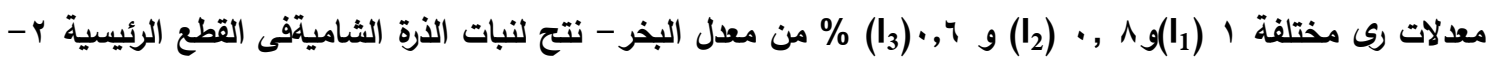

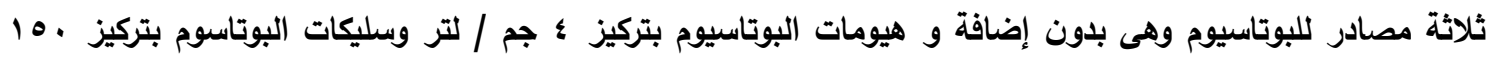

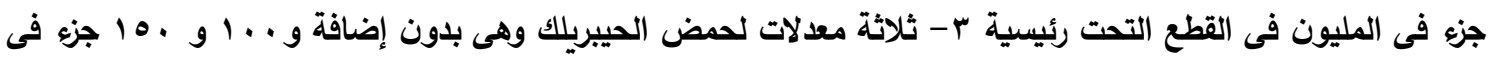

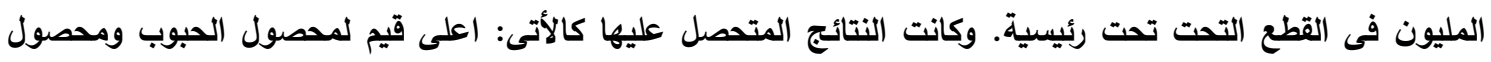

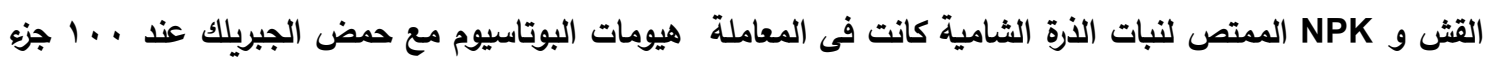

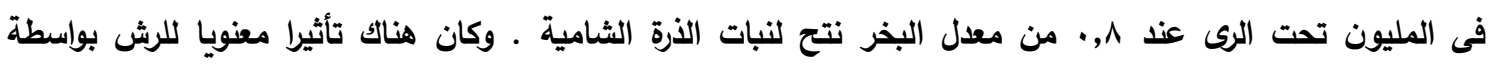

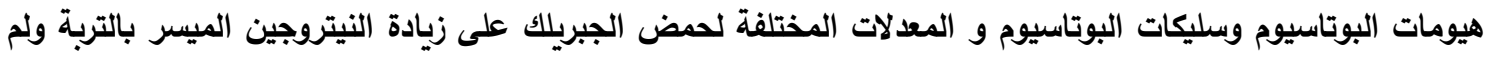
يتأثر بمختلف معدلات الرى. لم يتأثر الفوسفور الميسر فى التربة بمعاملات التجربة المختلفة بينما كان هناك التوات تأثيرا معنويا

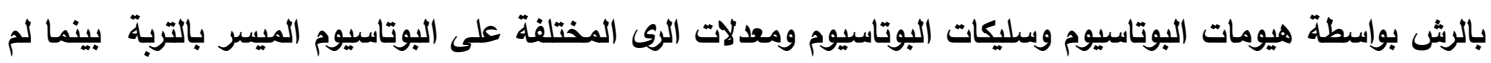

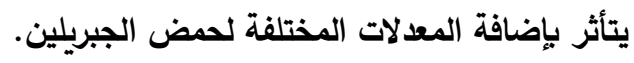

